\section{French information}

\section{New centre for Nancy}

Not before time, France is to reorganize its whole system for managing and distributing scientific information, the French government announced last week, thus responding to a long campaign by the Centre National de la Recherche Scientifique (CNRS), the principal research council, to bring the nation's libraries together in one great documentation system.

According to M. Goéry Delacote, director of scientific and technical information at CNRS, one target will be to catch up with the British Library Lending Division (BLLD), which is now central-

\section{West Germany}

\section{Support for biotechnology}

\section{Hamburg}

BY providing DM 1,000 million between 1985 and 1989, the Minister for Research and Technology, Heinz Riesenhuber (CDU), hopes to enable West Germany's biotechnological research to perform "jumps of perception" as chemical re search did 150 years ago.

One principal task is to expand the Gesellshaft für Biotechnologische For schung (GBF) into a national centre of biotechnology. Another is to promote the gene-centres in Cologne (plant cultivation), Heidelberg (immune defence, antibodies for cancer and rheumatism diagnosis) and Munich (chemical synthesis of nucleic acids) and to support two new centres for biotechnological process en gineering

Apart from financing basic research, $\mathrm{Dr}$ Riesenhuber, generally known as an obliging supporter of industrial research, plans to spend DM 120 million on a programme to further the biotechnological industry (Programm zu Förderung der biotechnologischen Industrie). Up to 40 per cent of expenses for projects will be refundable by the ministry up to a maximum of DM 600,000 . This programme covers developments in cell and tissue culture techniques, genetic engineering, biotechnical procedures with human, animal and plant cells or manipulated microorganisms, new biological systems of plant protection and the use of enzymes in medical and food research.

Development of new apparatus and devices for biotechnological production will also be promoted in the new programme. Dr Riesenhuber is optimistic about the prospects.

The total value of biotechnological products in West Germany came to DM 17 million in 1983, compared with an estimated DM 40,000 million worldwide.

Jürgen Neffe ized at Boston Spa in Yorkshire. Fifteen years ago, said Delacote, the CNRS documentation centre (CDST) and BLLD serviced 300,000 requests each year for photocopies of papers and other items in the sciences. Today, BLLD's computerized systems deliver 2,700,000 a year, while CDST's figure has not changed.

Something had to be done to improve the distribution of papers, a problem exacerbated by the poor financial condition of French university libraries. An opportunity came last year when the government offered to relocate the 350-staff CDST, now in Paris, in the depressed steel town of Nancy. Since many of the staff will probably choose to stay in Paris, this was an offer of jobs to Nancy, and of increased space to CDST

There will be a new institution, the Agence Nationale de l'Information Scientifique et Technique (ANSTI), whose job will be to coordinate not only CDST but also the many university libraries, the information systems of the medical research council (INSERM), the national collection of periodical catalogues (CCNP) which centralizes the journal lists of 2,300 French libraries, and other sources into one system which should look, as far as possible, simple and unified to the potential user.

According to Delacote, the aim will be not only to increase the volume of papers transported and transmitted in France but also to increase the speed of the various services from their present "rather long" average of 10 days from request to delivery to something more like one or two "We also want the system to be as comprehensive as possible", said Delacote, so that "95 per cent of the time" a user wil find that the paper requested is available.

ANSTI is expected to recommend that the new CDST centre at Nancy will provide the basic document delivery system, will host and develop the French abstracting database Pascal (for the hard sciences) and Francis (for the humanities and social sciences), and provide a centre for information management.

And while France may appear to be coming from behind in this area, it is also moving rapidly into the overtaking lane. Delacote believes a scientific information system like CDST must invest " 10,15 even 20 " per cent of its budget in research, and he has put FF2 5 million ( $£ 2$ million) of his budget into a project for automatic document delivery dubbed "Transdoc". This experimental electronic archiving and access system is comparing optical digital disks and a microfiche archive run by a computer, and should produce a clear choice of high-volume archiving system "by the end of this year". In this France is running "parallel to or even ahead of US systems".
More pork-barrel politics

\section{Washington}

DESPITE condemnation by the Association of American Universities, the National Academy of Sciences and the National Science Board, direct appeajs to legislators for funding of academic research facilities are continuing, and continuing to pay off. This year, once again, a number of construction grants to universities were approved on the floor of the House of Representatives and the Senate, virtually without debate; the grants had not been submitted to funding agencies previously or subjected to scientific peer review of any kind.

Topping the list this year is Dartmouth College, which, if the House agrees to the Senate's version of the 1985 supplemental appropriations bill, will receive a $\$ 15 \mathrm{mil}$ lion grant for construction projects at its engineering school.

The grant was approved by the Senate without a vote on an amendment offered by Senator Warren Rudman, who represents the state of New Hampshire, where Dartmouth is located. That same amendment also provided $\$ 10$ million for a "south wing rehabilitation project" at the Orgen Health Science University, located in the home state of Senator Bob Packwood, the chairman of the Senate Appropriations Committee.

Senator Orrin Hatch (Republican, Utah) introduced two amendments to provide support for a $\$ 6$ million cancer screening and research centre in St George, Utah, and a centre for the study of health effects of new energy technologies at the University of Utah.

Both projects had been authorized last year in amendments to the Head Start reauthorization bill which Hatch was able to push through in his position as chairman of the Labor and Human Resources Committee. Head Start is a programme that provides special tutoring to disadvantaged children.

Senator Robert Dole (Republican, Kansas), the Senate's majority leader, secured $\$ 200,000$ for a remote-sensing research project at the University of Kansas. The one contribution from the Democratic minority in the Senate was a $\$ \mathbf{\$ 5 0 0 , 0 0 0}$ amendment proposed on behalf of Senator Edward Kennedy of Massachusetts for a Chinese-US student exchange programme at Tufts University in Boston.

Earlier this year, Senator Alfonse D'Amato (Republican, New York) pushed through a measure to set aside $\$ 1$ million for a computer research programme at the University of Syracuse; the money comes out of a $\$ 25$ million university research initiative at the Department of Defense that was to be used entirely for investigatorinitiated, peer-reviewed grants for basic research. Stephen Budiansky 